Z Badań nad Książką i Księgozbiorami Historycznymi 2020, t. 14, z. 1 The Studies into the History of the Book and Book Collections 2020, vol. 14, no 1

\title{
Petr Poslední
}

Katedra literární kultury, Fakulta filozofická,

Univerzita Pardubice

petr.posledni@upce.cz

(iD) 0000-0002-0188-4245

\section{Underground in the Czech literature of the 1950s}

\begin{abstract}
In numerous collected source materials from the 1950s, it is necessary to distinguish texts created in the works of authors persecuted by the communist regime e.g. Catholic writers and those related to popular movement, from the authors deliberately abandoning official circulation e.g. supporters of the concept of total realism, embarrassing poetry and collage of various literary genres. Activities of the opposition in the second half of the 1950s resulted in the first attempts of culture liberalization. At that time literature has influenced film and theater opening up the way to the Prague Spring in the late 1960s.
\end{abstract}

Key words: Underground - terminological problems - unofficial circulation - Edition Midnight surrealism - ground for reform.

„Z Badań nad Książką i Księgozbiorami Historycznymi” - Udział zagranicznych recenzentów w ocenie publikacji; Stworzenie anglojęzycznej wersji wydawniczej publikacji; Digitalizacja tomów archiwalnych rocznika w celu zapewnienia otwartego dostępu do nich przez Internet oraz wdrożenie i utrzymanie cyfrowej platformy redakcyjnej - zadanie finansowane w ramach umowy nr 653/P-DUN/2019 ze środków Ministra Nauki i Szkolnictwa Wyższego przeznaczonych na działalność upowszechniającą naukę. 
Over the past decades, Czech literary scholars have managed to gather and organize a large number of publications from the post - war period, that were created outside the official circulation of the publication, and have negated the cultural policy of the Communist Party of Czechoslovakia. Nevertheless, there is still no definitive answer to the question, who can be counted among the underground (in Czech language activities in "podiemi"). Uncertainty regarding the definition of the subject of research is evident in the frequent swapping of concepts such as "literature in the catacombs", samizdat, or texts indicating the "internal emigration". Unclear concepts refer in particular to the worst Stalinist period (19481953), and partly also to the first signs of de-Stalinization (1954-1956), when due to ideological reasons and authority struggle within the Czech Communist Party, the divisions between official literary system and unofficial attitudes external to the system, a cultural center and its margins, forced opinions and independent thinking, were blurred. When interpreting underground, it sdepends on the chosen research strategy, whether we prefer one main discourse or vice versa - combination of complex discourses of various kinds ${ }^{1}$. It is clearly shown by literary experts recruited after the "velvet revolution" mainly from the younger generation, to what extent the strategy of research is important. Some of them - despite their good intentions - succumb to their experience with Husak's "normalization" of the Seventies and Eighties, while they can hardly imagine the creativity and lifestyle of writers in the specific conditions of Stalinism. That is why Martin C. Putna, dealing with Catholic literature, is of the opinion that writers who were guided by their own conscience and religious beliefs, have refused to cooperate with the regime during the Stalinist period, and preferred "internal emigration" and have been creating texts in a narrow circle of friends somewhere on the margins of the cultural life ${ }^{2}$. Another researcher - Martin Machovec - thinks that the main feature of the underground artists is their striving to demonstrate the absurd contradictions of the social life of the 50s, imaging the harsh reality, searching for the non-conventional means of expression especially inspired by surrealism or the new informel's reality (poetics of ordinary topics and language of urban folklore) ${ }^{3}$. Finally, the third historian representing the young generation - Martin Pilař - highlights the unity of the writer's personality and his literary work and, in accordance with Croce's aesthetics, developed in the Czech post-war conditions together with the philosophy of existentialism, and emphasizes the individual independence of each writer from the external conditions of cultural life.

\footnotetext{
1 Terminological problems accompany even factually rich publications - M. Přibań [a kol.], Česky literární samizdat 1949-1989, Praha 2018.

2 M.C. Putna, My posledni křestané, Praha 1994.

3 M. Machovec, Šestnáct autorů českého literárního podzemí (1948-1989), "Literární Archiv" 1991, vol. 25.

4 M. Pilař, Underground. Kapitoly o českém literárním underground, Brno 1999.
} 
It is enough, however, to recall specific events that followed the takeover of power by the communists in February 1948, in order to make us doubt the above term of underground. The first pole of enslavement of the creative thinking, is represented in the years 1951-1952 by the exclusion from the literary life of the Catholic writers and representatives of rural prose originating from the pre-war folk movement. This purpose was served by faking the lawsuit on the false charges of cooperation with "capitalist abroad", especially with the Vatican and the international agrarian movement, in order to sabotage the new people's democratic system. Outstanding artist - poets, novelists, translators, editors and literary scholars as Jan Zahradníček, Václav Renč, Jan Dokulil, Josef Kostohryz, Zdeněk Rotrekl or Zdeněk Kali-sta, constituting the first group, and Josef Knap, František Křelina, Václav Prokůpek, Bedřich Fučik and the others belonging to the second group, have received draconian court judgments from ten to twenty years in prison, two of them even life imprisonment. Penalties based on falsified evidences deviated from such practices in neighboring countries and can only be compared with processes in the Soviet Union. Prisoners were released only thanks to an amnesty in 1960 and have been partially rehabilitated until the late sixties during the Prague Spring. If the authorities exclude artists and scientists from literary life, the effects are often the opposite. An example is J. Zahradniček, a longtime friend of František Halas, who learned his own poems by heart, recited them to his fellow prisoners and secretly noted new texts (posthumously published in volumes entitled House of Fear and Four Years). The prison in Leopoldov and other places are conducive to establishing deeper human relationships and confirm the thought of Karl Jaspers, that the marginal living situations not only mean the test of human character, but also strengthen awareness of the ciphers of transcendence - the meeting of the Second, over individual orderliness or Faith, as a source of hope ${ }^{5}$. In the historical-literary research, therefore, we cannot cope only with historiographic and political science discourse. It is necessary to apply a similar degree of philosophical and religious discourse as well as philological and aesthetic discourse. The extreme situation leads to treating faith as a dialogue and shifts the burden of literary communication to the oral zone, or even to the joint storage of prohibited content in the form of narrative memory. In any case, the examples of Zahradniček and other imprisoned writers cannot be equated with the phenomenon of underground.

The second pole of Stalinist repression in the 1950s were the more perfidious methods of censorship, repeated criticism of writers in the daily press, or even slandering the private life of the artists. Also here, researchers should not limit themselves to the historiographic and political discourse, but it is necessary

5 J. Vojvodík, J. Wiendl, Jan Zahradníček. Poezie a skutečnost existence, Praha 2018. 
to use various discourses. Our task is to capture the multiple semantic contexts of a literary work, both in the form of an artifact and in the form of an aesthetic object associated with the publication of the book, literary criticism or reception by ordinary readers ${ }^{6}$. The communist authorities were at war with writers for the public space, and for symbols or toposes that are the components of cultural memory and refer to known figures and historical events. While the communist authorities imposed interpretations according to the pattern of class struggle, the "incorrect" writers tried to present the complexity of human existence and all the complications of human being.

Typical for the persecution of writers during the Stalinist period is the "matter" of Jarosław Seifert the poet who has published a lyrical-epic song entitled Song about Viktor (Písen o Viktorce), continuing "musical" poetry from the pre-war years. The lyrical subject and narrator leads in the song the fictional dialogue with the mad peasant girl, known from the nineteenth-century story of Božena Němcova titled Grandmother (Babička). In parallel with the dialogue, the poet expresses his own reflections of the memories by re-reading the story. Recalling love of his youth, the lyrical subject and narrator in one, empathizes in the authentic adventures at the Nermcova's family and at the same time in the Viktorka's love tragedy. The composition of the song is built on the contrasts of black and white, as well on light and shadow, and underlined by the iambic meter and sound echoes. But, to the surprise of the literary scholars and ordinary readers, Seifert was attacked by the young poet Ivan Skála. The critic wrote that the poet, under the guise of formal perfection, ignores a working man and shows the world that is alien to people who create socialism. In fact, it was not acceptable for the fanatic party members, the questioning by Seifert the Nermcova's image, that was created as a woman fighting for the social justice, and patriot persecuted by the Austrian authorities ${ }^{7}$.

As a second example we quote the conflict of the party activists with the poet Vladimír Holan. As long as the artist, shortly after the end of World War II, in the poems connecting the scenes from daily life with the pathos of the anthem, had exalted Soviet "liberators", he was unequivocally praised by leftist critics. However, when the artist at the beginning of the 50s has returned to the work of the pre-war and practiced the poetry with existential and linguistic attitude, in the paper of Ladislav Štoll was classified together with the deceased F. Halas, as typical representative of pessimistic, hermetic poetry and in relation to the whole of cultural life, even harmful. Despite the brave

$6 \quad$ For the purpose of studying literary culture based on understanding the so-called literariness by various subjects of cultural life, serves hermeneutics; vide P. Poslední, Jiný Conrad. Eseje o literární kultuře, Pardubice 2016.

7 Details about life and work are presented in the collection of articles in: Cteni o Jaroslavu Seifertovi. Hledání proměn autorovy poetiky, [ed.] J. Flaišman, Praha 2014. 
game the artist could not count on publishing his poems, he only deals with translations or editorial issues. In the cycle of works entitled Historie (Přiběhy), whether in the extensive song Night with Hamlet he writes about the tragic fate of each human being, and reflects on his existence from many cultural, historical and philosophical aspects. Above all, it moves the recipient with a special kind of imagination, in which metaphors and metonyms draw attention to the language itself, to the transfer of a particular substance to the abstract plane, and vice versa. As in the case of Seifert, Holan also offends dogmatists with his analytical reflections enriching the image of an ordinary man with a contradictory content ${ }^{8}$.

So where should one search for a real underground in such a context? The first to appear is a group of writers emerging from different generations - Zbyněk Fišer (nickname Egon Bondy), Jana Krejcarová, Pavel Svoboda and Ivo Vodsed'álek, with whom Bohumil Hrabal and Vladimír Boudník cooperated. Regardless of whether any of them had a permanent job, e.g. doctor Hrabal was employed as a laborer in the Kladno smelter near Prague and Fišer (Bondy) have been receiving a disability pension, all have refused to participate in the official literary life, exposing themselves to SB surveillance and allegation of illegal activity. Programmatically, they were convinced that any attitude disclosed publicly loses its authenticity, and moreover appearing in front of publishers or critics, would make the experiments with texts and spontaneous writing impossible. These authors have created the North (Pülnoc) edition in the single typed copies. Discussions over the texts were taking place together with translations of foreign literature.

Bondy, who considers himself a true Marxist, have created the volume of Total Realism (Totální Realismus, 1950), combining the texts parodying the newspaper style with his own notes contained in the diary:

I was reading a message from a trial of traitors

When you came

Shortly after you undressed

When I laid down beside you

You were nice as always

I read the message about their destruction

After you left ${ }^{9}$.

Bondy hasn't renounce political overtones in his poems and treated them as a polemic with the social realism. However, Hrabal - as noted by Austrian

8 The growing interest in Holan's poetry in Poland is testified by, among others two choices: Płacz symbolów, przeł., wybrał i wstępem opatrzył J. Waczków, Warszawa 1978; Poezje wybrane, przeł. M. Grzeszczak [i in.], Warszawa 1978.

9 Quote after own translation: Čitanka české literatury 4. Od roku 1945 do současnosti (2 polovina 20. století), [eds.] J. Holý, E. Lukeš, Praha 1996, p. 166. 
researcher Gertraude Zand - didn't agree with this assessment and has created an ironic portrait of the friend's alleged inventiveness.

A streetcar was taking off along the coast

Jesuskind Egon Bondy told me:

Please look there it seems

as if a tram leaves the coast!

And I politely smiled at him

We then walked under blooming acacias

Egon Bondy stuck his nails into my skin

and said: What a lark!

It looks like we are walking

under blooming acacias!

And I stopped smiling [...]

And I understood that he deleted the metaphor ${ }^{10}$.

In contrast to Bonde, the real discoverer of a new method of confronting disproportionate content e.g. journalistic phrase with the live slang, is I. Vodsed'álek, the author of the idea of the "trapné" poetry (in Polish he has indicated several connotations - shameful, embarrassing, stupid, humiliating, powerless poetry). Such confrontations build "lame" metaphor, suggesting to the reader a picture of a strange world using a newspeak or at least sick language. The poet in the introduction to the volume Flourishing Ukraine (Kretouci Ukrajina, 1950), imitates the logic of the party journalists and finally comes to a surprising punch:

The mythologizing Soviet heart builts a dream throughout culture that leads it to an unreal form. Nowadays the creation of any artificial paradises excites nobody; perfect sublimation is only possible when we approach reality in a dialectical way, using a better instrument of cognition - the paranoid-critical method $[\ldots]^{11}$.

Despite the courageous play with language and imagination reminiscent of early Dadaism, we should not overestimate the "North" edit, as do the authors of the chapters devoted to the poetry of the 50s. In the History of the Czech Literature developed in the Czech Academy of Sciences ${ }^{12}$ by using the collage method, a deeper understanding of the possibilities of language and imagination was presented by Jiří Kolár̆, the co-founder of Group 42 ("Skupina 42"). The poet, contrary to prior belief about the need for imaging the surrounding world, as the theoretician and critic of Group 42 Jindřich Chalupecky called for, he has applied after the war the technique of various layers of the spoken

10 G. Zand, Totaler Realismus und Peinliche Poesie - Tschechische Underground - Literatur 1948-1953, Frankfurt am. Main 1998; the same in translation: G. Zandová, Totální realismus a trapná poezie. Česká neoficiální literature 1948-1953, přel. Z. Adamová, Brno 2002, p. 112.

11 Ibidem in translation of P. Posledni.

12 P. Janoušek [a kol.], Dějiny české literatury. Vol. 2: 1948-1958, Praha 2007, p. 227-229. 
language, giving them a mythic dimension. In the work Liver of Prometheus (Prométheova játra, 1950), where Kolár combines poetry with prose and reflections on the essence of art, he uses intertextual references in the form of paraphrases or transcriptions of other works. The artist highlights the possible nodes of our being: the moments that determine the exit from everyday chaos and historical pitfalls. E.g. Kolár in relation to Zofia Nałkowska's At the Railroad shows that more important than the result of the narrative, is the search for a sense of human behavior:

Further from the track

someone was lying motionless.

But

People appeared slowly.

They stood and hesitantly

looked from a distance.

Some came,

others were leaving,

it was broad daylight.

A visible place from everywhere.

Her curly, ravenous hair

and black flaming eyes

under the lowered eyelids;

people have already known about the accident,

no one spoke to her.

She took right leg

in bloody hands,

and removed skirt from her knees;

Death sentence trapped in the knee

like a nail nailed her to the ground:

providing assistance

was threatened with death... ${ }^{13}$.

When SB found the typescript of the song, Kolař was unconditionally sentenced to six months in prison. After being released, however, in the Prague cafe Slavia he ostentatiously surrounds himself with the former members of the disbanded Group 42, joined by other representatives of the war generation - existentialist poet Josef Hiršal, jazz composer Jan Rychlík, critic and professor of Roman comparative studies Václav Černý, poet and translator Emanuel Frynta and other personalities of the opposition community. Kolař

13 Quote in translation of Leszek Engelking from the monograph - L. Engelking, Codzienność i mit. Poetyka, program i historia Grupy 42 w kontekstach dwudziestowiecznej awangardy i postawangardy, Łódź 2005, p. 258. 
refutes the myth about the necessary hiding from the public, but his position is strengthened by highly valued translations of the Anglo-American (Walt Whitman, Carl Sandburg, Virginia Woolf, Thomas S. Eliot), French (Samuel Beckett) and German (Christian Morgenstern) literature, and especially by works of art valued in the West ${ }^{14}$.

Surrealists play a special role in the unofficial circulation. After the sudden death of Karel Teig the leader of the Czech avantgarde from the 1920s to the Stalinist period, the leadership of the surrealist group takes over the poet and art theoretician Vratislav Effenberger. He is surrounded by the writers Zbyněk Havlíček, Karel Hynek, Ludvik Šráb and the artists Josef Istler, Václav Tíkal, Emila Mládková, Jan Kotík and Libor Fára. Every month since 1951, the group publishes collections of texts and graphics entitled "Zodiac signs" ("Znamení z verrokruhu"), to which from 1953 they attach collections - albums titled "Object 1-4" ("Objekt 1-4"). Artists in reference to the French pataphysics, used black humor, which appears e.g. in a poem by Zbyňka Havlíčka from a manuscript entitled Tse - tse (1951):

Under the flags of socialist happiness

the execution of the judgment was carried out in the audience [...]

Morality was puking around the neck

Naked women powdered dying fish ${ }^{15}$.

In another collection, Havlíček rejects sentimental melancholy:

The first lover cuts the rope from our heart

As a mother, cuts the umbilical cord from her belly

Where have you gone both? ${ }^{16}$.

The authors treat creation as an unconventional lifestyle, where a person reaches a distance from the absurd reality.

Unofficial artistic activity in the mid-1950s begins to echo among party decision-makers. Even the influential poet Vítězslav Nezval, who had been supporting socialist realism, has changed his front. In 1955, he suddenly appeared in the journal "Literární Nowiny" as an advocate of Guillaum Apollineir, considering him as an example of a revolution in art. After a few months, the young poet and essayist Milan Kundera joins Nezval in the magazine, paying his attention to many different poetics within such artists as Valéry, Pasternak and Holan. The war for the liberalization of culture is not just among decision-makers. The foundations of another way of thinking about literature are also created by individual personalities working in miserable conditions on the margins of cultural life. The modernist writer Josef Váchal, a mocker

14 See esay: V. Černý, Nástin básnické osobnosti Jiř́ho Koláře. Pokus o genzi básníka abstraktního, [in:] Tvorba a osobnost. Vol. 1, [eds.] J. Šulc, J. Kabíček, Praha 1992, p. 871-895.

15 Translation of the quote from: P. Janoušek [a kol.], Dějiny české literatury, op. cit., p. 225.

16 Ibidem. 
and occultist, lived exclusively on the orders of the wealthy art dealer Josef Portman by decorating his home "Portmoneum" 17 . Another "troublemaker" Catholic priest and poet Jakub Deml - exposing himself to church offices and hierarchs, spent time on correspondence with friends and has experimented in his diary with various species forms ${ }^{18}$. The writer and short story author Jaroslav Durych wrote historical works on the Czech-German borderland, provocatively referring to the baroque narrative, and took into consideration that they would never be published ${ }^{19}$. Finally, the poet, translator and graphic artist Bohuslav Reynek, who was living together with his family in a small country house, regardless of the circumstances, remained faithful to the spiritual mission of the art accordingly to Máritain ${ }^{20}$. All these personalities from the official and unofficial circulation have contributed to successive reforms of the cultural life in Czechoslovakia. Thanks to this, in 1958 the Czechoslovakian pavilion presented in the field of visual art at the World Expo in Brussels, received the first prize of Laterna Magica and a new wave of Czech film and small theaters stages has started. This way the road leading to Prague Spring was open.

\section{Bibliography}

Černý V., Nástin básnické osobnosti Jiřiho Koláře. Pokus o genzi básnika abstraktního, [in:] Tvorba a osobnost. Vol. 1, [eds.] J. Šulc, J. Kabíček, Praha 1992, pp. 871-895. Čteni o Jaroslavu Seifertovi. Hledáni proměn autorovy poetiky, [ed.] Jiří Flaišman, Praha 2014.

Čitanka české literatury 4. Od roku 1945 do současnosti (2 polovina 20. století), [eds.] J. Holý, E. Lukeš, Praha 1996.

Engelking L., Codzienność i mit. Poetyka, program i historia Grupy 42 w kontekstach dwudziestowiecznej awangardy i postawangardy, Łódź 2005.

Germain S., Bohuslav Reynek v Petrkové. Poutnik ve svém př́bytku, Havlíčkův Brod 2000. Hubáčková V., Rokytová B., Josef Portman (1893-1968). Na pomezi bibliománie, Praha 2019.

Janoušek [a kol.], Dějiny české Literatury. Vol. 2: 1948-1958, Praha 2007.

Machovec M., Šestnáct autorů českého literárního podzemi (1948-1989), “Literární Archiv" 1991, vol. 25. 2019.

17 V. Hubáčková, B. Rokytová, Josef Portman (1893-1968). Na pomezi bibliománie, Praha

18 M. Trávníček, Vstup do Demlových Šlépějí, [in:] J. Deml, Šlépěje. Vol. 1-3, Brno 1998, pp. 172-188.

19 P. Poslední, Pamět hor. Z literárního povědomí východnich Čech po roce 1945, Hradec Králové 2001, pp. 123-128.

20 S. Germain, Bohuslav Reynek v Petrkové. Poutník ve svém přibytku, Havlíčkův Brod 2000. 
Pilař M., Underground. Kapitoly o českém literárním underground, Brno 1999.

Płacz symbolów, przeł., wybrał i wstępem opatrzył J. Waczków, Warszawa 1978.

Poezje wybrane, przeł. M. Grzeszczak [i in.], Warszawa 1978.

Poslední P., Jiný Conrad. Eseje o literární kultuře, Pardubice 2016.

Poslední P., Pamět hor. Z literárního povědomí východních Čech po roce 1945, Hradec Králové 2001.

Přibań M. [a kol.], Česky literární samizdat 1949-1989, Praha 2018.

Putna M.C., My posledni krest’ané, Praha 1994.

Trávníček M., Vstup do Demlových Šlépěji, [in:] J. Deml, Šlépěje. Vol. 1-3, Brno 1998, pp. $172-188$.

Vojvodík J., Wiendl J., Jan Zahradniček. Poezie a skutečnost existence, Praha 2018.

Zand G., Totaler Realismus und Peinliche Poesie - Tschechische Underground - Literatur 1948-1953, Frankfurt am. Main 1998.

Zandová G., Totální realismus a trapná poezie. Česká neoficiální literature 1948-1953, přel. Z. Adamová, Brno 2002. 